DOI 10.18551/rjoas.2019-03.02

\title{
THE ACHIEVEMENT OF COMPETITIVE ADVANTAGE ON JAPANESE CULTURE FESTIVAL THROUGH VALUE CHAIN ANALYSIS CONCEPT
}

\author{
Gunawan Andhika P., Anshori Muslich \\ Postgraduate School, Faculty of Economy and Business, University of Airlangga, Indonesia \\ ${ }^{*}$ E-mail: andhikapramudya.g@gmail.com
}

\begin{abstract}
The purpose of this study was to obtain a value chain model of marketing, production and supporting activities at the Japanese Culture Festival and to seek answers to the ability of the Ennichisai festival to maintain the continuity of the festival for more than seven years without imposing costs on visitors. The discussion in this study uses contingency theory and the concept of value chain analysis as the basis for discussion. This research was examined using interview methods and documentation. The approach taken is a qualitative approach with case study and ethnographic methods. The researcher also used questionnaires as a supplementary data source that was described qualitatively. The results of this study are Ennchisai's cultural festival achieving competitive advantage with the uniqueness of Japanese culture that is able to make production costs in the production process more efficient, so Ennichisai is able to compete in the Industrial Festival scope in Indonesia.
\end{abstract}

\section{KEY WORDS}

Competitive advantage, Japanese culture festival, value chain analysis.

Japanese culture is a culture that is in great demand world-widely. Cultural flow originated from Japan to various parts of the world, especially Asia, is an interesting phenomenon to be discussed in the era of globalization (Saleha, 2016). Japan wield various unique ways to promote its culture, one of which is translating its promotional material into local language. Regional collaboration between media companies and promoters also give a big impact toward cultural spread. They role as a tool to distribute goods and services commodity (Otmazgin, 2008). Japan pop culture wield a big influence and it is a combination of television programs, comics, and modern music (Ngurawan et al., 2016).

One of the Japanese pop and traditional culture festivals in Indonesia is Ennichisai. An annual festival: that is held in Little Tokyo area, Blok-M, South Jakarta since 2010. This festival is a non-profit festival and focused on cultural exchange of Japan and Indonesia through foods exhibitions and art shows. The profit of this festival is used for social activities which mean to help the Blok-M region developmental.

In accountancy, according to Finney in a book written by Johnson (1932), there was going concern term which means unlimited sustainability. Japanese festival Ennichisai is a form of art of mankind that wields a power to maintain its survival. The event organizer seems to be able to make best decisions to increase the value of the festival, so it would still be competitive to similar annual festivals. A way to make a best decision is to effectuate management accounting function by identifying, collecting, measuring, and obtaining helpful information for users of internal organization (Hansen et al., 2009).

The development of an organization is the result of organization integration theory that fulfills each other through various adaptations to the discovering of best concept that fits to condition and characteristic of organization. Although, theoretically, almost all aspects of organization have been learned by experts to the discovering of specific understanding, however, theory and reality would be not resulting in an appropriate conclusion. That concept is the main core of contingency theory, since every organization owns a different resource to achieve its goal (Istanti, 2018).

Management accounting introduces a concept called strategic cost management. This concept explains that increasing consumer value to create sustainable competitive advantages could be created in various ways, one of which is value chain analysis. Value 
chain is a series of activities needed to bring a product or service from the concept stage to the production stage (Kaplinsky et al., 2001). Porter (1985) mentions that value chain is an activity that adds value to the company from process of obtaining sources to finishing process, in which consumers could obtain some benefits from it. The value chain point of view discusses the whole activity, so that good relationships and collaboration between organizations, suppliers and consumers could be established.

The value chain could be observed through main and supporting activities. The main activity is involved in the manufacturing of physical products or services, sales, and deliveries to buyers and after-sales services. The main activities cover internal logistics, operations, outside logistics, marketing and sales, and service. The main activities in the festival include stage and area production activities, marketing, promotions and publications, and the preparation of traditional and traditional stages. Supporting activities are activities that complement the main activities with various functions such as human resources, buyers, technology development, and administrative support (Porter, 1985). Supporting activities include organizational infrastructure, management of human resources, technology development, and procurement activities. Another important component in implementing an event is marketing. Marketing is a social and managerial process that involves individuals and groups to get the needs through creation and reciprocal exchange of products and values (Kotler et al., 2010).

Ennichisai is a Japanese cultural festival with free of entrance fee, however, this festival wields high profit and sustainability. This is rather interesting to conduct value chain analysis at the festival. Therefore, this study aims to discover the value chain model of Ennichisai Japanese Cultural Festival which is discussed comprehensively.

\section{METHODS OF RESEARCH}

This study uses a descriptive qualitative case study method. Qualitative research is carried out since this type of research could observe the problems in detail on the research subjects and objects (Creswell, 2012). This study was carried out by preliminary surveys, literature studies, field research and documentation. The object in this study is the value chain at the Ennichisai Japanese Cultural Festival in Blok M, South Jakarta. The Ethnographic approach was also chosen by the author since this study also involved values, behavior, beliefs, language and cultural exchange. Through ethnography, the author could comprehend the view from the author of prior studies. Ethnography realist is used in this study as this approach is able to support the author to collect an overview of the object of study through the involved people (Creswell, 2012). Study subject is a national-scale festival with rather complex activities. Study informants for the interview are initiators, marketing and creative directors, production directors, sponsorship representatives and booth tenant representatives.

Yin (2011) states that the analysis of evidence (data) is conducted by testing, categorizing, or recombining the evidence which is used as an analysis. The techniques of data analysis are:

- Identifying, describing and establishing model the processes of primary and secondary activities related to marketing and production at the Ennichisai Japanese Cultural Festival;

- Identifying the value chain in the activities at the making process of Ennichisai Festival, then explaining the advantages in each activity;

- Explaining the potential for developing competitive advantages. Triangulating the data by comparing the results interview transcripts from each informant, collected document and video documentation from the festival's committee.

\section{RESULTS AND DISCUSSION}

Ennichisai is the largest Japanese cultural festival in Indonesia which was established in 2010. Japanese cultural festival got 300,000 visitors in two days. 
Ennichisai consists of two words, Ennichi which means a temple festival and Sai which means big or magnificent festival. Like a community that wields faith, they take certain day to conduct worship activities. Japanese people hold temple services every month. Besides worshiping, they also used the moment to send prayers to deceased relatives. When the activity takes place, around the temple, many people also sell various kinds of worship, food and beverages.

The Ennichisai Festival was established from the desire of several entrepreneurs in the Blok $\mathrm{M}$ region to improve the economic conditions of Japanese companies that were sluggish in 2009, and as a consolation of longing for Japanese citizens living in Indonesia for a festival. In the profit-oriented festivals on service industry, organizers generally earn most of their income through ticket sales. However, Ennichisai does not charge fees to visitors.

"In the beginning, my friends and fellow Japanese restaurant owners in Blok $M$ area only gathered and told a story, until we began to question the Japanese festivals in Jakarta which charge entrance fee, because there is no entrance fee in Japan."

Based on the interview, there is an interesting point: where in Japan, organizing a festival of Japanese culture does not charge fees. Sources of funds were obtained from the contributions of entrepreneurs in the area around the festival.

The implementation of the Ennichisai festival did not start flawless at first. Mr. Daisei Takeya assisted by Mr. Takeshi Murohara and Ms. Daisei Takeya had to work hard to get funding.

"...I used to have a VIP restaurant on Blok-M called Royalty and the price of food was also rather expensive. Most of the people who came to this restaurant were the bosses of large Japanese companies in Jakarta. At that time, I said to them, I want to hold a Japanese festival in Blok-M, so I want to ask for a donation. They answered, "oh okay", but there was one thing that was difficult, the impression of Blok-M was a place of night entertainment, so they thought it was not good for the company's image. Nevertheless, personally, they continue to make donations. I also visited each of the other Japanese companies to do the same, and thankfully, they also contributed. If we (Japanese) go to the Blok-M area, we always feel safe, that's because the people there also protect us. I always say to them, "we are Japanese, and work in Indonesia; we have to give them blessings".

Ennichisai suffered a considerable loss in the first year. At that time, some of the initiators of Ennichisai had the desire not to continue the festival, this wish was conveyed by Mr. Takeshi Murohara. However, the desire to not to continue Ennichisai was not realized as there were many requests from volunteer festivals who wanted this event to be held again. Although they suffered a financial problem in the first year, however, they managed to attract the attention of people by getting approximately 40,000 thousand visitors.

This achievement and enthusiasm made Mr. Daisei Takeya and his friends continue to hold this festival until 2018. A significant increase in visitors was also one of the motivations to continue to hold this event.

As time passed by, Ennichisai began to be accepted by Jakarta people, quoted from rri.co.id. The Ennichisai Festival attracted the attention of the local government (South Jakarta regional government). This makes the regional government give full support because the Festival is considered to be able to maintain relations between Indonesia and Japan. In 2016, the South Jakarta government began to schedule the Ennchisai Festival as one of the local agendas. The following is a representation that shows the progress of the Ennichisai Festival every year.

The survey result shows that the tenants of booth were obtaining high profit margins, for above $90 \%$. It proves that $21 \%$ of booth tenants were very satisfied, $45 \%$ were satisfied, $25 \%$ felt quite satisfied and only $9 \%$ of the total 53 respondents felt dissatisfied. Followed by their ability to get profits as much as $58 \%, 26 \%$ turnover, and the remaining $15 \%$ suffered losses. The result also reflects their desire to participate Ennichisai again by $85 \%$ percent of those who are willing to return, and $15 \%$ are not.

At the festival, the organization of entertainment is carried out such as organizing entertainment in general. However, most of the viewers at Ennichisai use the benefit exchange model in the process. The artist's management requested time to appear on stage 
and the booth to promote their Talent Artist, by not charging transportation and accommodation fees to the organizers of the Ennichisai festival. The following is a statement from Mr. Daisei Takeya regarding the performance at Ennichisai:

"In the beginning, in order to invite taiko school to appear at Ennichisai, we had to pay eight million rupiahs. For a non-business festival, the number is quite big for us. The following year, we did not call them, so they asked, "Why were we not invited to the festival again?" I replied, "We did not have enough money." Then they understood and in fact their students also needed a place to be able to show publicly, then they offered the show for their students at Ennichisai festival. We, as the organizer, provided a stage and foods."

The following is a statement from Mrs. Emi Takeya:

"... talent agencies from Japan usually submitted their artists to be able to perform at Ennichisai at their own expense. This was intended for them as a way for their artists to be known in countries outside Japan. We, as the organizer, provide a stage for them and booth so they were able to promote their artists."

The following is a statement from Mr. Takeshi Murohara:

"... for stage shows, up to $80 \%$ of performers did not pay, but if a lot of performers from Japan came here, and because of the news would be sent back to Japan, please help us by introducing Japanese culture to Indonesians. However, we had to pay for professional drums and taiko, since we had to show them to Indonesian people, even though they only ask for compensation for accommodation costs".

The ability of Ennichisai festival to provide a good stage and a large number of visitors gave the organizer a high demanding power to the performers. This could provide a good impact on the festival's financial performance. Based on the calculations, with this demanding power, Ennichisai was able to save $129 \%$ on production costs of traditional stage content, and $143 \%$ on modern stage content. The savings contributed significantly to the ratio of Ennichisai's profit margin.

Ennichisai could provide revenues from activities other than the booths sellings. The activities were souvenir sales, and donations from colleagues of Mr. Daisei Takeya. Revenue was earned from Ennichisai T-shirts and knick-knacks selling; other revenues were earned from bank interest and other micro transactions, while Honoufuda is a voluntary contribution from colleagues of Mr. Daisei Takeya. The following are the results of an interview with Ms. Emi Takeya regarding Honoufuda:

"There is one habit that is still ongoing to get funding, namely Honoufuda, the contribution of Daisei-san's friends in Indonesia and Japan. Honoufudai means an Offering Card that is used as a gratitude for their contribution. We made them a name plates and installed the plates in front of Daisei-san's restaurant for a year."

Japanese people hold a high enthusiasm to participate in a matsuri (festival). According to Kunio (1977), Matsuri actually means for a religious ceremony to invite deities, or the event of a meeting between humans and gods. Through Matsuri, Japanese people could feel the presence of gods in life. Currently the organization of matsuri possesses two meanings: "Nihon Jin Rashisha" which means the peculiarities of the Japanese and "Kokoro Zuku Koto" which means the consciousness contained in the soul of the Japanese people. The purpose of distinctiveness and awareness of a person.

In the concept of value chain analysis, it is stated that there are four important scopes that deal a strong impact on focused competitive advantage. The scope is segment coverage, vertical coverage, geographical coverage and industry coverage.

1) Segment coverage related to the segmentation of products offered and the types of buyers served. The different needs or value chains needed to serve different products or buyers could produce focused competitive needs. The following is the comment of Mr. Daisei Takeya regarding the segment coverage at the Ennichisai Festival:

"...one of them said, Daisei tried to make Matsuri similar to Japan. We are Japanese, and we work in Indonesia, we have to give them blessings."

The interview reveals the scope of the segment to achieve: the people of Indonesian. The type of product offered is a festival of Japanese culture which is targeting the community in Blok-M region (South Jakarta). 
2) Vertical coverage according to Porter (1985), vertical coverage is all activities carried out independently and not dependent on other organizations. Ennichisai is an activity in the form of a festival, and is classified as a business in the form of services. The form of vertical coverage in this festival is that the overall production process is carried out by a team from Mr. Daisei Takeya. The initiator of the festival could have recruited the services of an event organizer, yet it was not realized. Festival organizers prefer to learn from the very beginning, since Japanese people assure that Japanese culture festivals could only be best-served by Japanese people. The decision to arrange the Ennichisai festival without event organizer services was the best decision, since in the long term, the benefits could be utilized maximally by the organizers for development or social purposes.

3) Geographical coverage, Ennichisai is a festival full of Japanese culture that needs human resources who comprehend on how to organize Japanese cultural festivals. Jakarta is the capital city of Indonesia which an international airport is provided. This provides a strategic position for Japanese people to be able to directly contribute the festival without incurring additional costs to come to a particular city. The characteristics of Blok-M region that is rife with Japanese employees could make it convenient for the festival to obtain the necessary resources.

4) Coverage of Industry, Ennichisai is the largest Japanese festival in Indonesia that does not charge entrance fees, compared to similar festival which charged entrance fees. However, it could maintain its existence in the festival industry. Based on the results of the study, the position of Ennichisai Festival seems to be better than non-profit festivals that charge entrance fees and similar paid profits. It shows that Ennichisai seize a unique competitive advantage and could not be imitated perfectly in any other Japanese culture festival industry.

\section{CONCLUSION}

Based on the interview with Ennichisai's organizer team, the results of a field survey of financial statement analysis, related journals and literature studies conducted by the author, the conclusions are:

Ennichisai is a festival that contains elements of Japanese culture, Matsuri. Matsuri possesses a positive meaning and enthusiasm for Japanese citizens to participate in the festival. The positive meaning is reflected in the spirit of the committee and the content of the Ennichisai festival. Reflecting these cultural elements indirectly forms the competitive advantage of the Ennichisai festival to be able to compete in creating good value for the festival itself and their consumers.

Ennichisai uses the concept of sales in marketing activities. The team makes maximum efforts to increase the number of sales when resistance occurs to its customers. The role of Mr. Daisei Takeya and Mr. Takeshi Murohara in using persuasive methods to convince sponsors was very influential in the success of sponsorship sales at the beginning of its establishment.

Production activities at the festival are carried out in the same way as the festival's production process in general. That is to conduct data collection on festival needs, then conduct a vendor search that is in accordance with the needs of the festival which offers the best quality.

Ennichisai possesses a strong appeal for the community so they are willing to participate. A participation in organizing the festival is by volunteering for the event. T-shirt, as an appreciation of participation, is able to provide cost efficiency in human resource management activities by $27 \%$.

Ennichisai does not charge tickets for visitors; however, it could maintain its existence in the festival industry due to the strength in creating high value for its consumers; so that the main source of income is from booth sales and sponsorship package sales. The uniqueness of Japanese culture also provides entertainment that brings many visitors. The large number of visitors to the festival also gave a strong attraction to the performers and is able to provide production cost efficiency by $129 \%$ in production activities on the traditional stage and $143 \%$ 
on the modern stage. The efficiency value makes Ennichisai is able to maintain its existence in similar industries with a margin profit value by $11 \%$.

\section{REFERENCES}

1. Creswell, J. W. 2012. Qualitative inquiry and research design: Choosing among five approaches: Sage publications.

2. Hansen, D. R., \& Mowen, M. M. 2009. Managerial Accounting. Edisi I, Salemba Empat, Jakarta.

3. Istanti, S. L. W. 2018. Teori Kontingensi, Sistem Pengendalian Manajemen dan Keluaran Perusahaan: Hasil Yang Lalu dan Arah Masa Depan. potensio, 18(02).

4. Johnson, G. L. 1932. Finney and miller's principles of accounting, introductory: Prenticehall.

5. Kaplinsky, R., \& Morris, M. 2001. A handbook for value chain research (Vol. 113): IDRC Ottawa.

6. Kotler, P., \& Armstrong, G. 2010. Principles of marketing: Pearson education.

7. Kunio, Y. 1977. The Japanese Festival. Guides to Japanese Culture (Tokyo: Japan Culture Institute, 1977) 37f.

8. Ngurawan, A. M., Pangemanan, S. S., \& Tielung, M. V. 2016. The Influence of Japanese Modern Culture Value toward Purchase Decision Making Process on Youth Society in Manado. JURNAL RISET EKONOMI, MANAJEMEN, BISNIS DAN AKUNTANSI, 4(2).

9. Otmazgin, N. K. 2008. Contesting soft Power: Japanese Popular Culture in East and Southeast Asia. International Relations of the Asia-Pacific, 8(1), 73-101.

10. Porter, M. E. 1985. Competitive Advantage: Creating and Sustaining Superior Performance. 1985. New York: FreePress.

11. Yin, R. K. 2011. Applications of case study research: Sage. 